SHEs: Conference Series 1 (1) (2018) 806-810

\title{
SMART: SOLUTIONS FOR LOW ENTREPRENEURSHIP STUDENTS IN A DISRUPTION ERA
}

Siti Kamsyati, Idam Ragil Widianto Atmojo

Universitas Sebelas Maret

sitikamsiyati@staff.uns.ac.id

\section{Article History}

accepted 09/07/2018

approved 01/08/2018

published 17/09/2018

Keywords

SMART, Disruption,

Entrepreneurship

\begin{abstract}
The purpose of this service is to improve the entrepreneurial spirit in the knowledge they pursue in the field of education. Subjects in this service were students of PGSD FKIP UNS. The method used in this service begins Workshop, Practice, Implementation. In the implementation of this training, the subject is asked to do the test, which is carried out before and after the implementation. Data analysis used using pretest and posttest analysis. The result of this activity was an increase in students' knowledge and understanding of entrepreneurship in the midst of disruption.
\end{abstract}

Social, Humanities, and Education Studies (SHEs): Conference Series https://jurnal.uns.ac.id/shes
p-ISSN 2620-9284

e-ISSN 2620-9292 


\section{PENDAHULUAN}

Pada masa sekarang peranan mahasiswa dalam mengimplementasikan pembelajaran Kewiraushaan (KWU) menjadi sangat penting, karena fenomena sekarang menunjukan bahwa KWU adalah suatu disiplin ilmu yang dapat dipelajari dan diajarkan, sehingga mahasiswa dapat mengetahui ada tiga kompetensi yang perlu dipelajari, yaitu menciptakan kesempatan, menciptakan ide-ide baru yang orisinil dan berani mengambil resiko serta mampu menghitungnya. Peran yang dilakukan perguruan tinggi adalah internalisasi dan implementasi nilai-nilai KWU, peningkatan keterampilan dalam aspek pemasaran, finansial, dan teknologi, dan dukungan berwirausaha. Dalam konteks pendidikan KWU, nampaknya partisipasi mahasiswa dan kemampuan perguruan tinggi perlu disinergikan, agar menyediakan layanan sebaikbaiknya, agar melahirkan student KWU. Dengan demikian, melalui pendidikan dapat direncanakan kebutuhan jumlah maupun kualitas lulusannya.

Lulusan perguruan tinggi cenderung menjadi pencari kerja dan sangat sedikit yang menjadi pencipta lapangan kerja. Masa tunggu lulusan perguruan tinggi untuk mendapatkan pekerjaan adalah selama enam bulan hingga tiga tahun hal ini menyebabkan terjadinya pengangguran terdidik yang tidak terhindarkan. Sebagian besar lulusan merasa tidak siap untuk membuka lapangan pekerjaan bagi dirinya sendiri atau menjadi wirausahawan.

Seseorang yang memiliki bakat KWU dapat mengembangkan bakatnya melalui pendidikan. Mereka yang menjadi wirausaha adalah orang-orang yang mengenal potensi dan belajar mengembangkannya untuk menangkap peluang serta mengorganisasi usaha dalam mewujudkan cita-citanya. Oleh karena itu, untuk menjadi wirausaha yang sukses, memiliki, bakat saja tidak cukup. Tetapi juga harus memiliki pengetahuan mengenai segala aspek usaha yang akan ditekuninya.

Sebagian besar mahasiswa cenderung memiliki minat yang relatif rendah terhadap KWU. Padahal mereka mempunyai hard skill dan soft skill untuk berwirausaha. Hard skill dan soft skill tersebut bisa disinergikan dengan cara membentuk mahasiswa-mahasiswa yang berjiwa wirausaha (entrepreneurship). Memupuk jiwa wirausaha ini merupakan langkah efektif yang harus dilakukan oleh universitas-universitas yang ada di Indonesia untuk menyinergikan hard skill dan soft skill sehingga nantinya mahasiswa tidak ada yang bingung setelah lulus dari universitas.

Adanya program-program yang mengarah pada peningkatan jiwa KWU ini, maka mahasiswa akan terbiasa dalam menghadapi proses pencapaian, inisiatif, kepemimpinan, kepercayaan diri, fleksibilitas, dan pembangunan team work dan ini akan menumbuhkan dengan sendirinya kompetensi soft skill dalam individu. Sedangkan dalam proses pengembangan kompetensi hard skill, di kampus mahasiswa harus diberikan mata kuliah KWU dalam bentuk teori dan praktek lapangan karena kita sebagi mahasiswa seringkali hanya mendapatkan teori yang begitu banyak tetapi praktek atau pengaplikasian lapangan yang tidak pernah kita lakukan, padahal dengan pengaplikasian lapangan ini justru akan menambah motivasi bagi para mahasiswa dalam membangun jiwa entrepreneur. Selain itu, untuk menumbuhkan motivasi berwirausaha dibutuhkan informasi mengenai keuntungan dalam berwirausaha, agar para pencari kerja khususnya mahasiswa dapat mengubah pola pikirnya untuk membuka lapangan kerja. Salah satu unit usaha yang berpotensi, dikembangkan dan sesuai dengan karakteristik mahasiswa program studi PGSD adalah bimbingan belajar (bimbel). Berdasarkan fakta yang terdapat di sekitar masyarakat Lembaga bimbingan belajar (LBB) saat ini sudah sangat menjamur di Indonesia. Hal itu terbukti dengan banyaknya jumlah lembaga yang tersebar hampir di seluruh daerah di Indonesia termasuk di Kota Surakarta. Mulai dari lembaga yang memang profesional dan sudah ternama di Indonesia serta lembaga-lembaga kecil yang masih merintis. Tentu saja itu 
dikarenakan meningkatnya jumlah siswa yang memerlukan belajar tambahan selain di sekolah. Selain itu, saat ini semakin banyak para orang tua yang mempercayakan pendampingan belajar anaknya kepada para guru bimbingan belajar (bimbel).

Berdasarkan hasil wawancara dan angket yang dilakukan secara random kepada 25 orang tua dari siswa sekolah dasar (SD) di Kota Surakarta diperoleh hasil bahwa terdapat tiga alasan utama orang tua memberikan tambahan belajar bagi anak mereka di luar jam sekolah yakni (1) Agar anak lebih menguasai materi ajar memiliki presentase $86 \%$ atau setara dengan 21 responden, (2) Orang tua tidak memiliki waktu untuk mendampingi anak belajar di rumah memiliki presentase $53 \%$ atau setara dengan 13 responden, (3) Agar anaknya mampu masuk SMP Negeri Favorit memiliki presentase $15 \%$ atau setara dengan 4 responden. Berdasarkan data tersebut maka dapat terlihat bahwa usaha bimbel memiliki prospek yang sangat tinggi. Perintisan usaha bimbel yang berkualitas tentu membutuhkan sumber daya manusia berkualitas juga.

Bimbel Binaan Prodi PGSD FKIP UNS yang memiliki Akreditasi A dan telah tersertifikasi ISO 9001:2008 diberi nama Bimbel SMART (Sebelas Maret Academic Revolution Tentor) yang telah berjalan selama kurang lebih satu tahun. Sesuai dengan nama dari rintisan unit usaha bimbel ini "SMART" berarti tentor-tentor yang revolusioner (berfikir kedepan/inovatif) yang notabene berasal dari Universitas Sebelas Maret.

Pengembangan unit usaha SMART selama kurang lebih satu tahun merupakan wadah bagi para mahasiswa yang memiliki minat jiwa wirausaha yang tinggi dibidang jasa dan menumbuhkan minat berwirausaha bagi mahasiswa yang lain. Bimbel SMART selama kurang lebih satu ini telah melatih mahasiswa untuk lebih mengimplementasikan ilmu yang diperolehnya ketika kuliah, menambah pendapatan/pemasukan bagi mahasiswa. Selain itu, bimbel SMART merupakan sarana bagi prodi untuk mengetahui sejauhmana tingkat kepuasan pengguna (steakholders) terhadap output/produk (mahasiswa/lulusan) yang dihasilkan dengan cara menanyakan langsung kepada orangtua/siswa yang mengikuti bimbel di SMART. Masukan dari steackholders tersebut merupakan input berharga bagi kemajuan dan peningkatan kualitas PGSD ke depan, sehingga lulusannya dapat bersaing didunia pekerjaan bahkan menjadi technopreuneur yang dapat menciptakan lapangan pekerjaan baru. Dan berdasarkan hasil review kegiatan Bimbel SMART berjalan dengan baik dan mendapatkan apresiasi penuh dari para pengguna jasa Bimbel SMART.

Bimbingan belajar SMART yang berhasil dirintis oleh Prodi PGSD FKIP UNS untuk memiliki ciri khusus dibanding dengan bimbel yang sudah ada. Ciri khusus tersebut 1)bimbel dapat dilakukan privat di rumah atau secara berkelompok di sekolah; 2) tentor adalah mahasiswa Prodi PGSD FKIP UNS yang sudah diseleksi dan dinyatakan layak dari segi akademik (IPK > 3,25), minimal semester IV, mengetahui model dan metode pembelajaran yang inovatif dan menyenangkan bagi anak SD, jujur, tanggung jawab, disiplin, pekerja keras (data diperoleh dari hasil wawancara, dokumentasi dan test micro teching); 3) sasarannya siswa SD dari kelas I hingga kelas VI, dengan materi semua matapelajaran yang diberikan di sekolah; 4) hasil bimbingan belajar akan dilaporkan kepada orangtua siswa setiap hari setelah selesai bimbel via SMS dan On line, serta siswa dan orang tua wajib memberikan masukan (feedback)/tingkat kepuasan terkait pelayanan tentor; 5) orang tua dan siswa diberikan kebebasan memilih tentor untuk bimbelnya dan waktu pelaksanaannya; 6) materi yang akan dibimbelkan juga bebas (boleh memperdalam materi dari sekolah, membahas pekerjaan rumah/PR, persiapan ujian akhir atau ujian kenaikan kelas) di samping siswa juga mendapatkan modul belajar sesuai dengan kelasnya.

Kegiatan pengabdian ini meliputi 9 tahapan kegiatan yaitu 1) Perintisan unit usaha bimbel SMART; 2) Penyusunan manajemen unit usaha (standart operasional prosedure/SOP 
SHEs: Conference Series 1 (1) (2018) 806-810

manajemen); 3) Rekuitmen tentor dan pembekalan tentor; 4) Penyusunan Perangkat unit usaha (modul bimbel dan aplikasi raport berbasis on line; 5) Sosialisasi dan promosi bimbel SMART di SD daerah Kota Surakarta; 6) Pelaksanaan Unit bimbel SMART; 7)Evaluasi unit bimbel SMART ; 8) pengembangan unit bimbel SMART menuju pengembangan unit yang lebih mandiri; 9) inkubasi mahasiswa dalam kegiatan dan manajemen bimbel. Tahap 1 hingga 6 telah dilaksanakan di tahun 1 (2017) mendapatkan hasil Pelaksanaan kegiatan Bimbel SMART pada tahun pertama mendapatkan respon yang positif dari siswa, orang tua, dan tentor (dalam hal ini mahasiswa) terbukti bimbil SMART mendapatkan keuntungan tahun pertaman sebesar Rp. 1.100.000,- (satu juta seratus ribu rupiah). Pada tahun kedua (2018) akan dilaksanakan tahap 7 dan 8 yakni tahapan Evaluasi dan Pengembangan unit usaha. Tahapan kegiatan evaluasi didasarkan pada pelaksanaan pada tahun 2017 yang meliputi manajemen pengelolaan, pemasaran dan supervisi tentor guna meningkatkan pelayanan yang prima kepada konsumen. Pengembangan bimbel SMART tahun 2018 difokuskan pada 3 aspek yaitu: 1. Manajemen administrasi, 2. Pengelolaan sumber daya manusia, 3. Peningkatan sarana dan prasarana

\section{METODE}

Subjek dalam pengabdian ini terdiri mahasiswa PGSD FKIP UNS terdiri dari Mahasiswa semester $3 \mathrm{~s}$.d semester 7 . Metode yang digunakan dalam pelatihan ini Workshop, Praktik, Implementasi. Teknik pengumpulan data menggunakan teknik tes. Teknik analisis yang digunakan menggunaka analisis presentase dengan menggunakan pretest dan posttest.

\section{HASIL DAN PEMBAHASAN}

Bagian Berdasarkan hasil pretest yang dilakukan sebelum pelaksanaan kegiatan pengabdian menunjukkan bahwa mahasiswa program studi Pendidikan Guru Sekolah Dasar yang terlibat sebagai peserta dalam kegiatan pengabdian dengan jumlah 50 mahasiswa yang terdiri dari semester 3 sampai dengan semester 7 menunjukkan bahwa kemampuan mahasiswa jiwa kewirausahaan dan pengetahuan tentang kewirausahaan mahasiswa masih terhitung rendah. Hal ini ditunjukkan dari data yang menyatakan bahwa masih terdapat 42 mahasiswa atau sebesar $84 \%$ belum tuntas dalam mengerjakan soal pre test, atau hanya sekitar 8 mahasiswa (16\%) yang berhasil lulus.

Mahasiswa yang berhasisl lulus dalam pretest merupakan mahasiswamahasiswa yang ikut andil atau berpartisipasi aktif dalam kegaitan bimbel di luar instansi, sedangkan mahasiswa yang belum lulus merupakan mahasiswa yang belum memiliki pengalaman di dalam bidang usaha. Setelah dilaksanakan postest setelah mengikuti kegiatan bimbingan belajar SMART jiwa kewirausahaan mahasiswa meningkat dengan tingkat ketercapaian $86 \%$ atau sekitar 43 mahasiswa lulus dan sekitar 7 mahasiswa atau 14\% mahasiswa yang belum lulus. Hal ini menunjukkan terjadinya peningkatan sebesar $70 \%$ atau sekitar 35 mahasiswa. Secara grafis dapat dilihat dalam grafik 1.1 berikut: 
SHEs: Conference Series 1 (1) (2018) 806-810

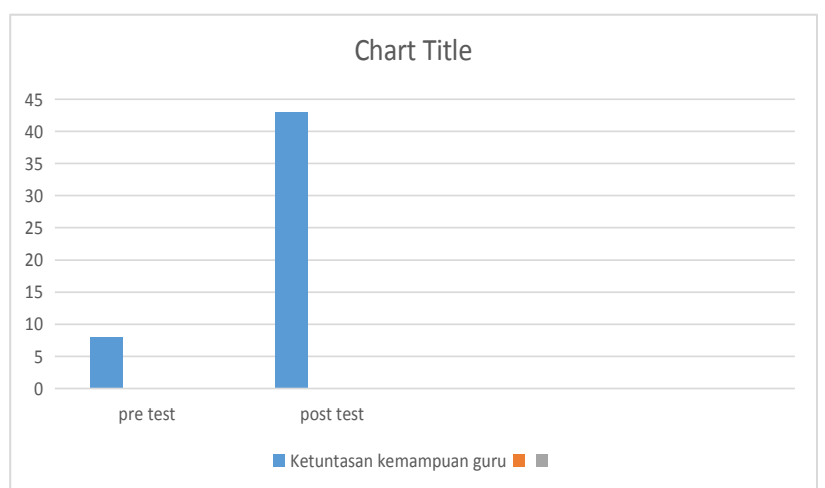

Gambar 1.1 Grafik Hasil perbandingan pre test dan post test kemampuan guru SD

Berdasarkan hasil pretest dan posttest yang telah dilakukan ditemukan fakta bahwa bimbel SMART yang dilaksanakan memberikan dampak yang signifikan terhadap jiwa kewirausahaan mahasiswa. SMART merupakan kegiatan yang diberikan dalam bentuk pelatihan dan dengan tujuan dasar melatih mahasiswa untuk melatih dan meningkatkan jiwa kewirausahaan mahasiswa. Kegiatan workshop atau pelatihan dengan mendatangkan narasumber ahli yang merupakan pakar di bidang tersebut secara tidak langsung sudah memberikan dampak yang positif melalui proses komunikasi yang baik. Sebagaimana dijelaskan dalam Rosmawaty (2010) bahwa komunikasi kelompok adalah komunikasi dalam kelompok kecil orang, dengan tujuan antara lain untuk berbagi informasi, membantu mengembangkan gagasan bahkan membantu untuk memecahkan masalah, baik secara formal maupun tidak formal. Situasi formal yang dibangun ketika pelaksanaan Pelatihan atau Workshop akan membantu menyelesaikan permasalahan yang dihadapi oleh mahasiswa dalam mengembangkan jiwa kewirausahaan mahasiswa.

\section{SIMPULAN}

Berdasarkan dari hasil analisis data yang telah dilakukan dapat disimpulkan bahwa dengan pelaksanaan Bimbel SMART dapat meningkatkan jiwa kewirausahaan dan pengetahuan tentang kewirausahaan mahasiswa. Simpulan ini didapatkan dari hasil analisis pre test dan post test yang dilakukan ketika pelaksanaan kegiatan.

\section{DAFTAR PUSTAKA}

Daryanto. 2011. Media Pembelajaran. Bandung: PT Sarana Tutorial Nurani Sejahtera Mohamad Surya. 2015. Strategi Kognitif dalam Proses Pembelajaran. Bandung: Alfabeta CV

Margaret E. Bell G. 1994. Belajar dan Membelajarkan. Jakarta: PT Raja Grafindo Persada

Rosmawanty HP. (2010). Mengenal Ilmu Komunikasi. Widya Padjadjaran

Sudarwan Danim. (2015). Pedagogi Andragogi, dan Heutagogi. Bandung: Alfabeta Uyoh Sadulloh. (2015). Pedagogik (IImu Mendidik). Bandung: Alfabeta 